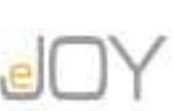

Şahin, A. / Journal of Yasar University, 2021, 16/61, 278-297

\title{
Zombi Şirketlerin Risk Düzeyi ile İlişkili Olan Finansal Özellikleri: İSO 1000 Firmaları ile Bir İnceleme
}

\section{Financial Features Related to the Risk Level of Zombie Companies: An Investigation with ISO 1000 Firms}

\author{
Arzu ŞAHIN, Adana Alparslan Türkeş Bilim ve Teknoloji Üniversitesi, Türkiye, asahin@atu.edu.tr \\ Orcid No: 0000-0002-9944-1791
}

\begin{abstract}
Öz: Bu çalışmanın amacı, Türkiye'de zombi şirket varlığını ve özelliklerini araştırmak ve zombi şirketlerin finansal özellikleri ile zombi risk seviyesi arasındaki ilişkiyi incelemektir. Bu amaçla 1993-2019 yılları arasında ISO 1000 üretim işletmesi arasından en az üç yıl negatif öz sermaye kriterlerine göre 32 zombi firma belirlenmiştir. Bu 32 zombi şirketin zombi risk düzeyi ile zombiye dönüşmeden önceki yılın firma büyüklügüu, sermaye türü ve sektör değişkenlerinin göstergeleri arasındaki ilişkiler tek değişkenli yatay kesit regresyon, lojistik regresyon ve korelasyon analizi ile incelenmiştir. Zombi risk düzeyini, zombi olarak geçirilen süre (zombi süresi) ve zombi olunan ilk yılda negatif öz kaynağın aktife oranı (zombi derinliği) göstergeleri temsil etmiştir. Analiz bulgularına göre; büyüklük göstergeleri (satış, aktif, öz kaynak, kar, ihracat ve çalışan sayısı) ile zombi süresi arasında pozitif ilişkiler vardır. Zombi olmadan önceki yll nispeten daha büyük olan firmalar daha uzun süre zombi olarak kalmıştır. Sonuç olarak, zombi olmadan önce, nispeten daha büyük olan ISO 1000 firmalarının zombi risk seviyesi daha yüksektir. Ayrıca, analiz sürecinde tespit edilen 557 negatif öz kaynak kaydının ve 52 zombi işletmenin gelişimine göre; her iki gruptaki firma sayıları yıllar içinde azalmış ve iki grubun da sektör dağılımında en yüksek payı sırasıyla; dokuma sanayi, gıda maddeleri sanayi ve madencilik-taş ocakçılı̆̆ı sektörleri almıştır.
\end{abstract}

Anahtar Kelimeler: Zombi Şirketler, Zombi Risk Düzeyi, Negatif Öz kaynak, ISO 1000

JEL Sinıflandırması: G32, G33, L60

\begin{abstract}
The aim of this study is to investigate the zombie company presence and features in Turkey and to examine the relationship between the zombie companies' financial characteristics and the zombie risk level. For this purpose, according to minimum three years negative equity criteria, 32 zombie firms were determined among ISO 1000 manufacturing enterprise between 1993 and 2019. The relationships between the zombie risk level of these 32 zombie companies and the indicators of firm size, capital type and sector variables of the year before they became zombies were analysed with univariate cross section regression, logistic regression and correlation analysis. The years spent as a zombie (zombie duration) and, the ratio of negative equity to assets in the first year of being a zombie (zombie depth) represented the zombie risk level. According to the analysis findings; there are positive relationships between size indicators (sales, assets, equity, profit, exports, and number of employees) and zombie duration. Companies that were relatively larger in the year before they became zombies remained zombies for longer. As a result, before becoming zombies, the zombie risk level of ISO 1000 companies, which are relatively larger, are higher. In addition, according to the development of 557 negative equity records and 52 zombie enterprises detected during the analysis process; firm numbers in the both groups have declined over the years and the sectors of the textile manufacturing, food manufacturing and mining and quarrying had the highest share in the sector distribution of the two groups, respectively.
\end{abstract}

Keywords: Zombie Companies, Zombie Risk Level, Negative Equity, ISO 1000

JEL Codes: G32, G33, L60

\section{Giriş}

Finansal açıdan sıkıntıda olup faaliyetine devam etme ihtimali düşük olduğu halde finansal kurumların veya hükümet politikalarının desteği ile varlığını sürdürülebilen işletmeler zombi (yaşayan ölü) işletme olarak nitelendirilmektedir. Rekabetçi olmayan ve verimsiz zombi işletmeler, kendi iflasları yanı sıra sağlıklı firmalara aktardıkları riskler dolayısı ile 
sürdürülebilir ekonomik büyüme için önemli bir tehdit oluşturmaktadır (Caballero, Hoshi \& Kashyap, 2008: 1944; Urionabarrenetxea, San-Jose \& Retolaza, 2016: 307; Urionabarrenetxea, Garcia-Merino, San-Jose \& Retolaza, 2017: 408-409; Blažkova \& Dvouletý, 2020: 1).

İşletmeler için zombi kavramı ilk olarak Kane (1987)'nin tasarruf ve kredi sigortası sektöründe yaptığı çalışmada kullanılmıştır (Kane, 1987: 77; Blažkova \& Dvouletý, 2020: 21; Wang \& Zhu, 2020: 1-3). Ölçülebilir göstergelere göre finansal sıkıntıda olan, iyileşme umudu çok düşük olduğu için piyasadan çıkması gereken (Blažkova \& Dvouletý, 2020: 3), ancak banka kredileri ve hükümet destekleri ile faaliyetine devam eden (Hoshi, 2006: 48; Wang \& Zhu, 2020: 1; Zhu, He, Wang, Ye \& Liang, 2019: 107) firmalar zombi olarak tanımlanmıştır. Aynı zamanda faiz ödemelerini karşılamada sürekli sorunlar yaşayan ve yaşlı (McGowan, Andrews \& Millot, 2017: 3), kar etmeyen (Caballero vd., 2008: 1944), borç ödemesi yapmaya yetecek kadar kar elde etmeyen ve genç (Banerjee \& Hofmann, 2018: 67-68), verimsiz ve borca batık (Ahearne \& Shinada, 2005: 363; Fukuda, Kasuya \& Nakajima, 2006: 488), iflas etmiş (Fang, Gozgor, Lau, Wu \& Yan, 2020: 2) veya negatif öz kaynağa sahip olan (Urionabarrenetxea vd., 2016; Urionabarrenetxea vd., 2017; Blažkova \& Dvouletý, 2020) ancak sözü edilen finansal sıkıntılara rağmen faaliyette olan firmalar da zombi olarak ifade edilmiştir.

Bütün öz kaynağını kaybetmesine rağmen faaliyetine devam eden negatif öz kaynaklı firmalar genellikle zombi firmaların en riskli (en uç veya ekstra zombi) durumu ile bağlantılı olarak kullanılmıştır (Urionabarrenetxea vd., 2016: 307; Urionabarrenetxea vd., 2017: 408; Blažkova \& Dvouletý, 2020: 2). En kötü sermaye yapısına sahip negatif öz kaynaklı firmalar, varlıklarının defter değeri borçlarını karşılayamayan, sadece borçlanarak yatırım yapan ve nakit üretimi olmadan kontrata dayalı borçlarını ödeyemeyen ve bu yönleri ile geleneksel teoriler ile açıklanması zor olan firmalardır. Ayrıca, bu firmalarda ahlaki tehlike sorunu oldukça belirgindir çünkü kaybedeceği bir şeyi bulunmayan ortakların riskli kararlar alarak firsatçı davranmaları, riskin gerçekleşmesi durumunda kayıpların ekonomik bağlantılı üçüncü taraflara transfer edilmesi sonucunu doğurmaktadır ve firmanın tüm fonunu sağlayan kreditörlerin riskli kararlarda kontrolü bulunmamaktadır (Urionabarrenetxea vd., 2016: 307-315). Ekonominin olumsuz bir gerçekliği olan negatif öz kaynaklı şirketler taşıdıkları bu risklere rağmen geleneksel işletme teorilerince olağan dışı olarak kabul edilerek birçok araştırma örneklemin dışında tutulmuş (Urionabarrenetxea vd., 2016: 307; Mackek, 2018: 682; Blažkova \& Dvouletý, 2020: 2) ancak zombi firmalara odaklanan literatür ile ampirik çalışmalara daha çok dahil olmaya başlamıştır.

Türkiye'nin On Birinci Kalkınma Planında zombi firmalar şu şekilde ifade edilmiştir: Finansal sistemin sağladığı krediler ile yaşamaya devam eden ancak verimlilik ve 
istihdam açısından ekonomiye katkıları oldukça düşük ve olası kredi riski yüksek olan

KOBİ’ler zombi firmalardır. (On Birinci Kalkınma Planı: 66, www.sbb.gov.tr).

Zombi firma olgusu öncelikle Japonya'da 1990'lı yıllarda başlayan uzun süreli ekonomik durgunluğun sebeplerinden biri olarak çalışmalara konu olmuş ve 2008 krizinin ardından Avrupa ülkelerinde incelenmeye başlanmıştır (Blažkova v\& Dvouletý, 2020: 4-5). Uluslararası yazın (bkz. bölüm 2) zombi firmaların ekonomiye olumsuz etkilerini inceleyen çalışmalar (birinci literatür grubu) ve zombi firmaların özelliklerini araştıran daha güncel çalışmalar (ikinci literatür grubu) olmak üzere iki başlık altında incelenebilir. Birinci grup, zombi firmaların ve bu firmalara verilen desteklerin sağlıklı firmalara, sektöre ve ekonomiye verdiği zararları istihdam artışı, yatırım verimi, finansman olanağı, sektör girişi...v.b açılardan incelenmiştir. İkinci literatür grubu, zombi firmaların zombi olmadan önce ve/veya zombi iken taşıdığı finansal özelliklere, zombi olmayan firmalardan ayrıştıkları noktalara ve sektörel ve coğrafi dağılımına odaklanmıştır. Türkiye verileri ile zombi firma konulu iki çalışma özetine ulaşılmıştır. Dinçer, Pektekin ve Tekin Koru (2019), Türkiye İstatistik Kurumu (TÜİK) verileri ile zombi firmaların özelliklerine, sektör ve il bazında dağılımına ve istihdam ve verimliliğe olan etkisine odaklanmıştır. Kaplanoğlu ve Yükçü (2019), Borsa İstanbul imalat sanayi firmaları arasında zombi firma varlığ 1 ve iki finansal oran açısından farklılaşma durumu üzerinde durmuştur.

$\mathrm{Bu}$ çalışmanın amacı, teknik olarak iflas etmesi gerekirken belirli bir süre faaliyetine negatif öz kaynak ile devam eden zombi işletmelerin Türkiye'de varlığının ve özelliklerinin araştırılması ve zombi olmadan önceki dönemin finansal özellikleri ile zombi risk seviyesi ilişkisinin firma düzeyinde incelenmesidir. Bu amaç ile 1993-2019 yılları arasında İstanbul Sanayi Odası en büyük 1000 sanayi kuruluşu (İSO 1000) arasından seçilen 32 zombi imalat işletmesinin zombilik risk seviyesi belirlenmiş ve zombi olmadan önceki yıla ait finansal değerlerin zombi risklilik düzeyi ile ilişkisi yatay kesit regresyon, lojistik regresyon ve korelasyon analizi ile incelenmiştir. Ayrıca 32 işletmeden oluşan örneklemin seçim sürecinde tespit edilen 557 adet negatif öz kaynak kaydının ve minimum üç yıl negatif öz kaynak kaydına sahip olan 52 zombi işlemenin bazı finansal özellikleri veri seti bölümünde (bkz. bölüm 3.1.1 ve bölüm 3.1.2) değerlendirilmiştir.

\section{Literatür Özeti}

Zombi firmaların sağlıklı firmalara risk transferi yaparak ekonomiye verdiği zararları araştıran çalışmalar, kronolojik sıralama da dikkate alınarak, literatür özeti bölümünün ilk grubu olarak sınıflandırılmıştır. Bu çalışmanın amacına daha yakın olan ve nispeten daha güncel tarihli 
çalışmaları içeren ikinci literatür grubu, zombi firmaların karakteristiklerini ve sağlıklı firmalardan farklılıklarını inceleyen çalışmalardan oluşmuştur. Literatür özetinin son bölümünde ise Türkiye verileri ile gerçekleştiren iki çalışma özetinde yer alan bilgiler bulunmaktadır.

İlk grupta olup zombi işletmelerin Japon ekonomik durgunluğu dönemine odaklanan çalışmalardan Ahearne ve Shinada (2005), 1970-2001 döneminde halka açık firmaları inceleyerek zombi yoğun sektörlerde verimliliğin düştüğünü ancak pazar payının bu sektörlere doğru kayarak üretkenlik azalışını şiddetlendirdiğini göstermiştir. Hoshi (2006), 1990’larda finansal destek alan zombi firmaları zombi olmayan firmalarla kıyaslamış ve zombi firmaların işgücü yaratma potansiyeline verdiği zararı ortaya çıkarmıştır. Caballero vd., (2008) 1990'larda yaşanan durgunlukta zombi yoğun sektörlerde yaşanan istihdam ve verimlilik düşüşlerinin etkili olduğu yönünde bulgular elde etmiştir. Imai (2016), 2000'lerde finansal açıdan desteklenen küçük ölçekli zombi işletmelerin varlığından dolayı yatırım veriminin düştüğü sonucuna varmıştır.

Wang ve Zhu (2020), 2006-2016 yıllarında Çin'de zombi firmaların, zombi olmayan üretken firmaların finansman ve yatırım olanaklarını düşürerek sektörel ve ekonomik gelişmeye zarar verdiğini raporlamıştır. Zhu vd., (2019) çalışmasında, 2007-2017 dönemi Çin ekonomisinde Şangay ve Shenzhen borsalarında zombi firma dağılımının dengeli olduğu, 2016 ilk çeyreğinden sonra yaşanan ekonomik gelişme ile zombi probleminin azaldığı ve 2017 yılında zombi payı ile imalat sektörünün birikmiş borçlanması arasında pozitif korelasyon olduğu sonucuna varmıştır. Aşırı kapasite sorunu ile zombi firma sorununu ilişkilendiren Shen ve Chen (2017), Çin üretim sektörünün 2011-2013 dönemi firma düzeyi verileri ile yaptığ çalışmasında, her iki sorunun da Çin'in kuzeydoğu ve batı bölgelerinde, ağır kimya endüstrilerinde ve devlete ait sektörde daha ciddi olduğunu göstermiştir. Analiz sonuçları, sağlıklı firmalara kıyasla daha düşük kapasite kullanım oranı ile faaliyet gösteren zombi firmaların, kaynak dağılımına zarar vererek zombi olmayan firmaları olumsuz etkilediğini göstermiştir.

Urionabarrenetxea vd., (2016), Avrupa Birliğinde negatif öz kaynak düzeyi ve risk transferi açısından zombi firmaların ekonomiye etkisini, Avrupa ülkeleri arasında farklılaşma durumunu ve kriz etkisini incelenmiştir. İki farklı veri seti (birinde 2012 verileri, diğerinde 2009-2012 verileri) kullanılan çalışma sonuçlarına göre; şirketlerin yaklaşı \%20'si negatif öz kaynağa sahiptir ve bu şirketlerin geliri Avrupa Birliği GSYH'sının \%10'una denk gelmektedir. Milli gelirin \%10'unun riskte olması rekabet (sektöre giriş engelleri) ve etik (ahlaki tehlike) açıdan ekonomiye zarar vermektedir. Zombi firmaların ülkeler arasında dağglımda kültürel ve coğrafi 
farklar bulunmadığı gibi krizin de belirleyici etkisinin olmadığı dolayısı ile zombi sorununun dönemsel değil yapısal olduğu belirtilmiştir. Ayrıca orta ve büyük ölçekli firmaların \%9’u negatif öz kaynağın \%88'ini oluşturmakta olduğundan büyük firmaların başarısız olmasının üçüncü taraflara vereceği zarar daha yüksek olacaktır ve bu sebeple Avrupa otoritesinin büyük firmalara daha farklı davranması önerilmektedir (Urionabarrenetxea vd., 2016: 314).

McGowan vd., (2017)'1n 2003-2013 yıllarında OECD (Organisation for Economic Cooperation and Development) ülkelerinde gerçekleştirdiği ampirik çalışma bulguları; zombi firmaların sermaye tahsisi üzerindeki bozucu etkisinin zombi olmayan firmaları işgücü, yatırım, üretkenlik ve büyüme bakımından kısıtladığı yönündedir. Banerjee \& Hofmann (2018), 14 gelişmiş ülkenin halka açık firmalarının 1987-2016 dönem verileri ile, 1980’lerin sonlarından itibaren artan zombi firma varlığında finansal esnekliğin (faiz oranı düşüşü şeklinde) etkisi olduğunu ve zombi firmaların diğer firmaların yatırım ve işgücüne zarar verdiğini ortaya koymuştur. Yazarlar, faiz oranı indirimlerinin kısa süreli faydaları ile zombi firmaların neden olduğu uzun süreli zararlarının kıyaslanması gerektiği konusunda öneride bulunmuştur.

Literatür özetinin ikinci bölümünde yer alan çalışmalardan Urionabarrenetxea vd. (2017), 2010-2014 yılları arasında İspanya'da zombi firmaların varlığını araştırmış ve oluşturdukları bir endekse göre en yüksek risk taşıyan zombi firma karakterini sektör, bölge ve ölçek bakımından analiz etmiştir. Zombi endeksinde negatif öz kaynağı destekleyen dört boyut, negatif öz kaynak sorununun; devamlılığı, diğer firmalara yayılma etkisi, orta vadede düzeltilebilme ihtimali ve aciliyetidir. Yazarlar 2010-2014 yıllarında öz kaynağı negatif olan 1271 firma (mikro-işletmeler dışında) arasından en yüksek endeks değerine sahip en riskli (ekstra zombi) firmaların daha az düzenlemeye tabi olan sektörlerde faaliyet gösterdiğini, büyük iş yapılanmalarının olduğu bölgelerde konumlandığını ve daha büyük ölçekli firmalar olduğunu ortaya çıkarmıştır.

İngiltere'de finansal kaldıraç üzerinde global finansal krizin ve firmaya özgü faktörlerin etkisine odaklanan Javaheriafif (2017)'in tez çalışmasının diğer amaçları; zombileri belirlemek ve zombilik durumunun belirleyicilerini tanımlayan bir model geliştirmektir. Çalışmada, Londra Borsasında FTSE (Financial Times Stock Exchange) 250 endeks firmalarının 20042012 verileri ile, krizin zombi varlığını artırdığı ve zombi olma olasılığının finansal kaldıraç derecesi ile pozitif, buna karşı11k karlı1ık, nakit yaratma kapasitesi ve kar payı dağıtma yeteneği ile negatif ilişki içinde olduğu yönünde bulgular elde edilmiştir. Mackek (2018), Avrupa ülkelerinde 2012-2017 arasında zombi ve zombi olmayan firmaları kıyaslamayı, zombi firmaların finansal özelliklerini belirlemeyi ve bu özelliklere göre zombi firmaları tahmin etmeyi amaçlamıştır. Fang vd., (2020), Çin borsasında 1997-2018 yılları arasında işlem gören 
firmaların üst düzey yönetici cinsiyetinin zombi olasılığı üzerindeki etkisini incelemiştir. Araştırmada, bilgi paylaşımı ve kurumsal yönetim alanlarında kaliteyi iyileştirme yönleri ile kadın yöneticilerin, kurumsal riski ve zombi olasılığını önemli ölçüde azaltabileceği gösterilmiştir. Buna karşılık, yerel yönetimlerden ve finans kuruluşlarından alınan krediler ve sübvansiyonların şirketlerin zombi olasılığını artırdı̆̆ı da elde edilen bulgulardandır.

Blažkova ve Dvouletý (2020), Çek gıda sektöründe faaliyet gösteren 1730 firmanın 2003 'ten 2015'e kadar olan dönemde üç yıl devamlı olarak negatif öz kaynağa sahip olan ekstra zombi firmaları ve bu firmaları zombi olmayan firmalardan ayıran özellikleri incelemiştir. Çek ekonomi politikası ve hükümet düzenlemelerinin zombi firma oluşması için bir zemin hazırlamadığını kabul ederek işletmeye ilişkin faktörlere odaklanan yazarlar; yasal form, büyüklük, sektör, lokasyon, bölge ve yaş faktörlerinin bir fonksiyonu olarak zombi olma olasılığını analiz etmiştir. Zombi ve zombi olmayan firmalar arasında yaş, yasal statü, büyüklük ve sektör açısından farklılık olduğunu gösteren çalışma bulguları; zombilerin çoğunlukla büyük şehirlerde konumlandığını ve daha küçük, orta tecrübede ve sınırlı sorumlu firmalar olma eğiliminde olduğunu ortaya çıkarmıştır. Blažkova ve Dvouletý (2020) ayrıca 382 zombi firma arasından zombi olmadan önce ve sonra verisi temin edilebilen 43 işletme (258 gözlem) ile firmaların zombi olmadan önceki özelliklerini panel lojistik regresyonları ile araştırmıştır. Analiz sonucunda varlık azalışı, borç artışı, karlılık azalışı ve önceki yıl zararlarının birikmesi şeklindeki olumsuz performans gelişmeleri ile finansal durumun kötüleşmesinin zombi şirket olma olasılı̆̆ını artırdığı ortaya çıkmıştır.

Literatür özeti bölümünün son kısmında Türkiye'de zombi firma varlığı, özellikleri ve/veya ekonomiye zararlarını inceleyen iki çalışma (özetleri) yer almıştır. Dinçer vd., (2019) 20042015 yılları TÜİK sanayi ve hizmet verilerini kullanarak zombi firmaları, özelliklerini, sektörel ve il bazında dağılımını belirlemeyi ve zombi firmaların istihdam ve verimlilik üzerine etkisini incelemeyi amaçlamıştır. Kaplanoğlu ve Yükçü (2019), Borsa İstanbul imalat sanayi firmaları arasında 2008-2018 döneminde faiz karşılama oranı ve Tobin Q oranlarından faydalanarak zombi firmaların varlığını ve bu iki oran açısından farklılaşma durumunu araştırmayı hedeflemiştir.

\section{Veri Seti ve Analiz}

$\mathrm{Bu}$ bölümde; veri setinin oluşturulma süreci, özellikleri ve belirlenen örneklem üzerinde gerçekleştirilen analiz sonuçları yer almaktadır. 


\subsection{Veri Seti}

Analiz tarihi itibari ile İSO ilk 500'ün 1993 yılından 2019 yılına kadar olan verilerine ve İSO ikinci 500’ün 1997 yılı ila 2018 yılı verilerine ulaşılmıştır. İSO ilk 500 için 1993-2019 ve İSO ikinci 500 için 1997-2018 yıllarını kapsayacak şekilde İSO 1000 için analiz dönemi, 1993-2019 yılları olarak belirlenmiştir. İSO 1000'e giren imalat firmalarının 1993-2019 y1lları verilerinin yıllık olarak incelenmesi sonucunda 557 adet negatif öz kaynak kaydına rastlanılmıştır. Negatif öz kaynaklı firmalardan en az üç yıl üst üste öz kaynağı negatif olan (zombi firma olarak kabul edilen) 52 işletme belirlenmiştir. Belirlenen 52 zombi işletme arasından ilk negatif öz kaynak kaydının görüldüğü yıldan bir önceki yıl İSO 1000 arasında yer alarak verisine ulaşabilen, bir başka ifade ile analizin amacına uygun olan, 32 imalat işletmesi bulunduğu tespit edilmiştir.

Çalışmanın analizi 32 işletme üzerinde gerçekleştirilse de bu bölümün alt başlıklarında 557 negatif öz kaynak kaydının (bkz. bölüm 3.1.1) ve negatif öz kaynağı minimum üç yıl devam eden 52 zombi işletmenin (bkz. bölüm 3.1.2) özellikleri de incelenmiştir. Regresyon ve korelasyon analizine tabi tutulan 32 zombi işletmenin özellikleri ise bölümün son alt başlığ1 (bkz. bölüm 3.1.3) altında yer almaktadır.

\subsection{1. İSO 1000 Negatif Öz kaynak Kayıtları}

Örneklem belirleme sürecinde öncelikle İSO 1000'in 1993-2019 yılları arasında raporladığ1 negatif öz kaynak kayıtları tespit edilmiştir. 27 yıllık dönemde belirlenen 557 adet negatif öz kaynak kaydının, aynı firmanın birden fazla yıl negatif öz kaynağa sahip olması nedeni ile 248 farklı firmaya ait olduğu görülmüştür. 325'i İSO ilk 500'e ve 232'si ikinci 500'e ait olan 567 negatif öz kaynak kaydının analiz dönemine dağılımını içeren Şekil 1 ile de görüldüğü gibi Türkiye'nin en büyük imalat sektörü firmalarının negatif öz kaynak kaydı yıllar içinde azalmıştır. Çeşitli küresel ve yerel kaynaklı ekonomik sıkıntılı dönemleri içeren 2009 öncesi dönemde ortalama olarak negatif öz kaynaklı 30 üretim işletmesi İSO 1000 sıralamasında yer almış iken 2010 yılından sonra bu ortalama 7'ye düşmüştür. 557 negatif öz kaynak kaydının kamu-özel sermayeli firma dağılımda, özel sektör payının yüksek olduğu ve \%26'sının (146 işletme) kamu sermayeli (kamu sermaye payı \%50 ve üzerinde olan) işletmelere ait olduğu görülmüştür. 


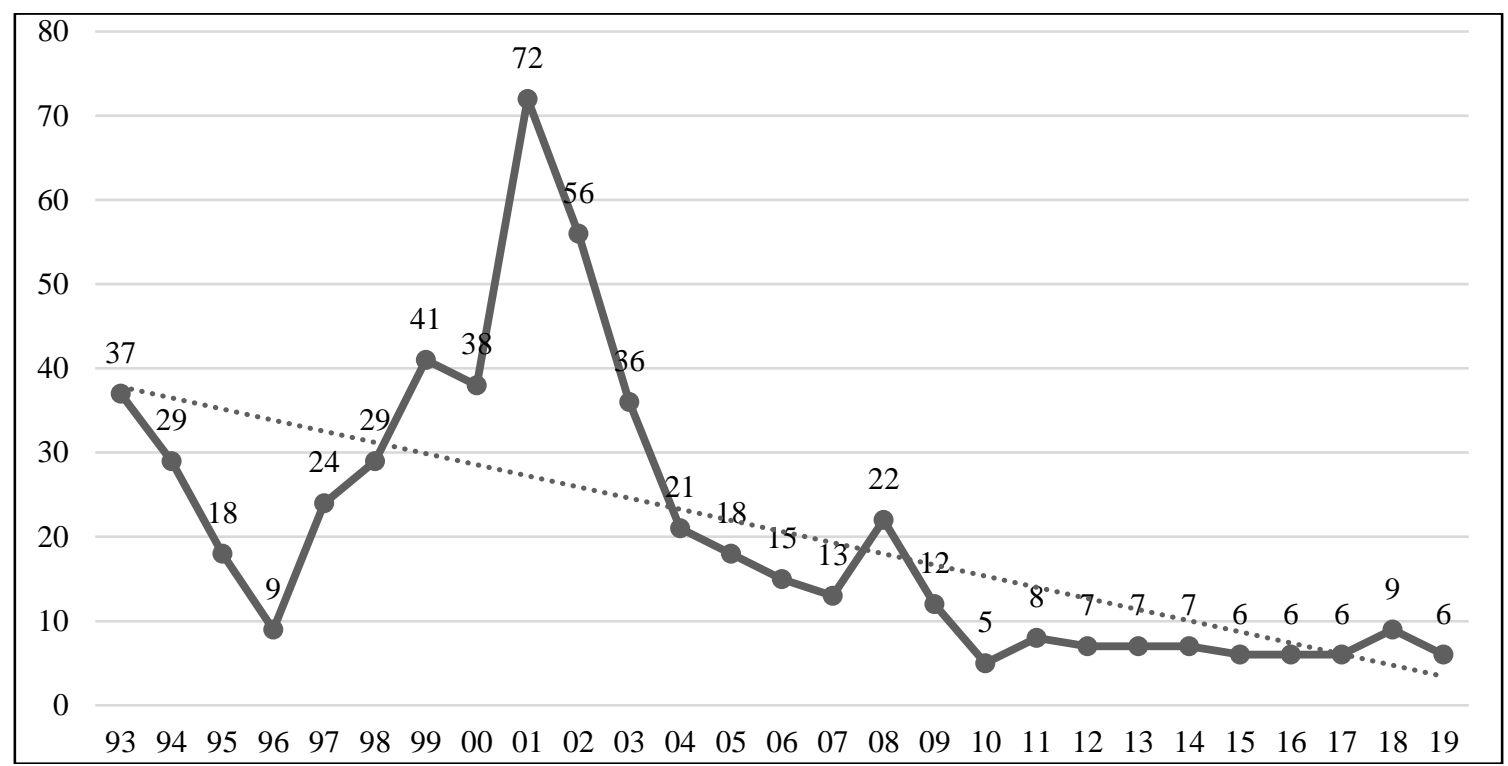

Şekil 1. 557 Negatif Öz Kaynak Kaydının Yıllar İçinde Değişimi

Kaynak: ISO 1000 (ISO ilk 500+ ISO ikinci 500, www.iso500.org.tr) verileri kullanılarak yazar tarafindan oluşturulmuştur.

Not. Yatay (x) eksen, 1993-2019 yıllarını göstermektedir. 93 ila 19'a kadar olan yatay eksen değerleri 1993 ila 2019'a kadar olan yılları ifade etmektedir. 1993-1996 yıllarında ve 2019 yılında sadece İSO ilk 500 firma verileri dikkate alınabilmiştir.

557 negatif öz kaynak kaydının ISIC (International Standard Industrial Classification of All Economic Activities) Revizyon 2 ekonomik faaliyet koduna göre sektörel dağılımda, \%1'in üzerinde pay alan 17 sektör Tablo 1 ile verilmiştir. Tablo 1'den izlendiği gibi negatif öz kaynak kayıtları dokuma sanayi ve gıda maddeleri sanayinde yoğunlaşmış olup iki sektörün toplamdan aldığg pay \%42'dir. Toplam negatif öz kaynak kayıtlarının \%51'i üç sektöre ait olup bu sektörler sırası ile 1) dokuma sanayi, 2) gıda maddeleri sanayi, 3) madencilik ve taş ocakçılığı şeklindedir. Tablo 1'in son sütunu (ISO 1000 pay1), ISO 1000 içinde sektör yoğunluğunu ifade etmekte olup ilgili sektörün firma sayısının 1000'e bölümü ile bulunan yıllık oranların analiz dönemi ortalaması alınarak hesaplanmıştır. Buna göre ilk üç sırada yer alan sektörlerin negatif öz kaynak payı sektör yoğunluğunun üzerindedir. 
Tablo 1. 557 Negatif Öz Kaynak Kaydının Sektörel Dağılımı

\begin{tabular}{|c|c|c|c|c|c|}
\hline & $\begin{array}{c}\text { ISIC } \\
\text { Rev. } 2 \\
\text { Sektör } \\
\text { Kodu }\end{array}$ & $\begin{array}{l}\text { ISIC Rev. } 2 \\
\text { Sektör Sinıfi }\end{array}$ & $\begin{array}{c}N O ̈ \\
\text { Saylsl }\end{array}$ & $\begin{array}{c}N O ̈ \\
Y \ddot{u} z d e s i\end{array}$ & $\begin{array}{l}\text { ISO } \\
1000 \\
\text { Payı }\end{array}$ \\
\hline 1 & 321 & Dokuma Sanayi & 119 & 21.4 & 15.0 \\
\hline 2 & 311 & G1da Maddeleri Sanayi & 118 & 21.2 & 15.0 \\
\hline 3 & 210 & Madencilik ve Taşocakçıllı̆ 1 & 47 & 8.4 & 2.2 \\
\hline 4 & 352 & Diğer Kimyasal Ürünler Sanayi & 33 & 5.9 & 5.4 \\
\hline 5 & 384 & Taşıt Araçları Sanayi & 32 & 5.7 & 7.2 \\
\hline 6 & 371 & Demir-Çelik Ana Metal Sanayi & 26 & 4.7 & 6.8 \\
\hline 7 & 312 & Başka Yerde Sınıflandırılmamıș Gıda Maddeleri Sanayi & 21 & 3.8 & 1.9 \\
\hline 8 & 369 & Taş ve Toprağa Dayalı Diğer Sanayi & 20 & 3.6 & 5.2 \\
\hline 9 & 341 & Kağıt ve Kağıt Ürünleri Sanayi & 18 & 3.2 & 2.9 \\
\hline 10 & 382 & Makine Sanayi (Elektrikli Olanlar Hariç) & 17 & 3.1 & 3.1 \\
\hline 11 & 372 & Demir-Çelik Dışında Ana Metal Sanayi & 16 & 2.9 & 2.9 \\
\hline 12 & 383 & Elektrik Makineleri, Aletleri ve Cihazları Sanayi & 15 & 2.7 & 5.4 \\
\hline 13 & 356 & Başka Yerde Sınıflandırılmamış Plastik Ürünler Sanayi & 14 & 2.5 & 3.8 \\
\hline 14 & 322 & Giyim Eşya Sanayi & 12 & 2.2 & 5.6 \\
\hline 15 & 351 & Ana Kimya Sanayi & 11 & 2.0 & 2.5 \\
\hline 16 & 400 & Elektrik Sektörü & 10 & 1.8 & 1.6 \\
\hline 17 & 332 & Ağaç, Mobilya ve Mefruşat Sanayi & 6 & 1.1 & 1.1 \\
\hline
\end{tabular}

Kaynak: ISO 1000 (ISO ilk 500+ISO ikinci 500,www.iso500.org.tr) verileri ile yazar tarafindan hazırlanmıştır.

Not. 1993-1996 yıllarında ve 2019 yılında sadece İSO ilk 500 firma verileri dikkate alınabilmiştir. NÖ: negatif öz kaynak. NÖ Sayısı: İlgili sektörde analiz dönemi süresince görülen negatif öz kaynak kayıt sayısıdır. NÖ Yüzdesi: NÖ Sayısının 557 adet negatif öz kaynak kaydına oranıdır. ISO 1000 Payı: Her yıl her bir sektörün firma sayısının 1000 firmaya oranının analiz dönemi ortalamasıdır.

İncelenen dönemde negatif öz kaynak raporlayan firmaların negatif öz kaynak raporlanan yıllarda İSO veri tabanında yer alan özellikleri incelenmiştir. Brüt katma değer verisi bulunan 548 kaydın ortalama brüt kar marjı \%4’tür. 556 kaydın aktif devir hızı ortalaması 1,5'tir. 541 kayda ait dönem kar marjının -\%54,6 olduğu ve aktif kar marjının -\%47,5 olduğu izlenmiştir. Bu ortalamalar, 1993-2019 yıllarının herhangi birinde negatif öz kaynak kaydı ile İSO ilk 1000 firması arasında yer alan imalat işletmelerinin; brüt katma değerlerinin düşük ve karlılıklarının önemli düzeyde negatif olduğunu göstermektedir. Aktif devir hızının ise Türkiye ortalamalarına yakın ancak üretim işletmeleri için verimli olarak kabul edilen düzeyin altında olduğu söylenebilir.

\subsection{2. İSO 1000 Zombi İşletme Kayıtları}

Bir işletmenin sermaye yapısına göre zombi olarak nitelendirilebilmesi için diğer çalışmalarda olduğu gibi (Urionabarrenetxea vd., 2017; Blažkova ve Dvouletý, 2020) negatif öz kaynak durumunun geçici olmaması gerektiği kabul edilmiş ve minimum üç yıl devam eden negatif öz kaynak kaydı şartı aranmıştır. Dolayısı ile bir firmanın zombi firma olarak nitelendirilmesi ve örnekleme dahil olmasının koşulu, İSO 1000'e girdiği yılların herhangi bir döneminde en az üç 
yıl boyunca negatif öz kaynak raporlamasıdır. Bu nitelikte olan 52 imalat işletmesi belirlenmiştir.

Sürekli negatif öz kaynak koşulu, öz kaynağı aralıklı olarak üç veya daha uzun yıllar negatif olan firmaları örneklem dışında ${ }^{1}$ bırakarak bir kısıt oluştursa da iki yıldan sonra öz kaynağın pozitife dönmesi finansal sıkıntılı durumunun geçici olma olasılığını artırdığı için negatif öz kaynak sürekliliği aranmıştır. Analizin herhangi bir döneminde üç yıl art arda negatif öz kaynağa sahip firmaların karşılaştırılmasında yıl etkisinin dikkate alınmaması ikinci bir kısıt olup, analizde büyüklük sıralamalarının ve/veya nispi değerlerin kullanılması ve regresyon analizi yanı sıra korelasyon analizi kullanılması ile bu kısıt giderilmeye çalışılmıştır. Öz kaynakların negatif olmasına sebep olan faktörlerin ${ }^{2}$ tespit edilememesi ve defter değeri ile piyasa değeri arasındaki farkın karşılaştırılamaması da araştırmanın diğer kısıtları olarak sayılabilir.

Şekil 2, zombi olarak nitelendirilen 52 işletmenin yıllara dağılımını göstermekte olup yatay eksende yer alan yıllar, ilk sürekli (minimum üç yıl) negatif öz kaynak kaydının görüldügü yılı (zombi başlangıç yılı, [ZBY]) ifade etmektedir. Örneğin, 2001 yılında sekiz firma ilk kez negatif öz kaynak kaydı raporlamış ve eksi öz kaynak durumu minimum üç yıl devam etmiştir. Zombi işletme sayısının yıllar içinde azalan eğilimi, negatif öz kaynak sayısının gelişimine (Şekil 1 ile görülen) benzemektedir ancak zombi işletmelerde azalma 2001 yılından sonra belirgindir. 2001 yılına kadar negatif öz kaynak ile en az üç yıl faaliyet gösteren İSO 1000 işletme sayısı ortalama olarak 4 iken 2002 ve sonraki yıllarda bu ortalama 1'in altındadır.

Şekil 1 ve Şekil 2 verileri birlikte yorumlanırsa, 2001 yılına kadar öz kaynağı negatife dönen ve en az üç yıl bu aşırı borçlanma durumunda kalan firma sayısında artış yaşamış ve 2001 yılında her iki durumda olan işletme sayısı en yüksek düzeye ulaşmıştır. 2002 ila 2008 yı1ları arasında negatif öz kaynaklı firma sayısı ortalama olarak 25 iken bu firmalardan ortalama 1,4’ü zombi haline dönüşmüştür. 2009 yılından sonra gerek negatif öz kaynaklı firma sayısı (ortalama 7) gerek negatif öz kaynak ile minimum üç yıl faaliyet gösteren zombi firma sayısı (ortalama $0,5)$ azalmıştır.

\footnotetext{
${ }^{1}$ Örneğin 2006, 2005, 2003 ve 2002 yıllarında negatif öz kaynağa sahip olan bir firmanın 2004 yılında öz kaynağının negatif olmaması veya ilk 1000 firma arasında yer almaması, konu firmayı örneklem dışında tutmuştur. ${ }^{2}$ Mohrman ve Stuerke (2014), olay çalışması niteliğinde olan makalesinde incelediği firmanın 2001 yılında negatife dönen öz kaynağında maddi olmayan duran varlıkların ekonomik değerinin altında kayıtlanmasının ve firmanın borçlanarak hisse geri alımı yapmasının etkili olduğunu göstermiştir.
} 


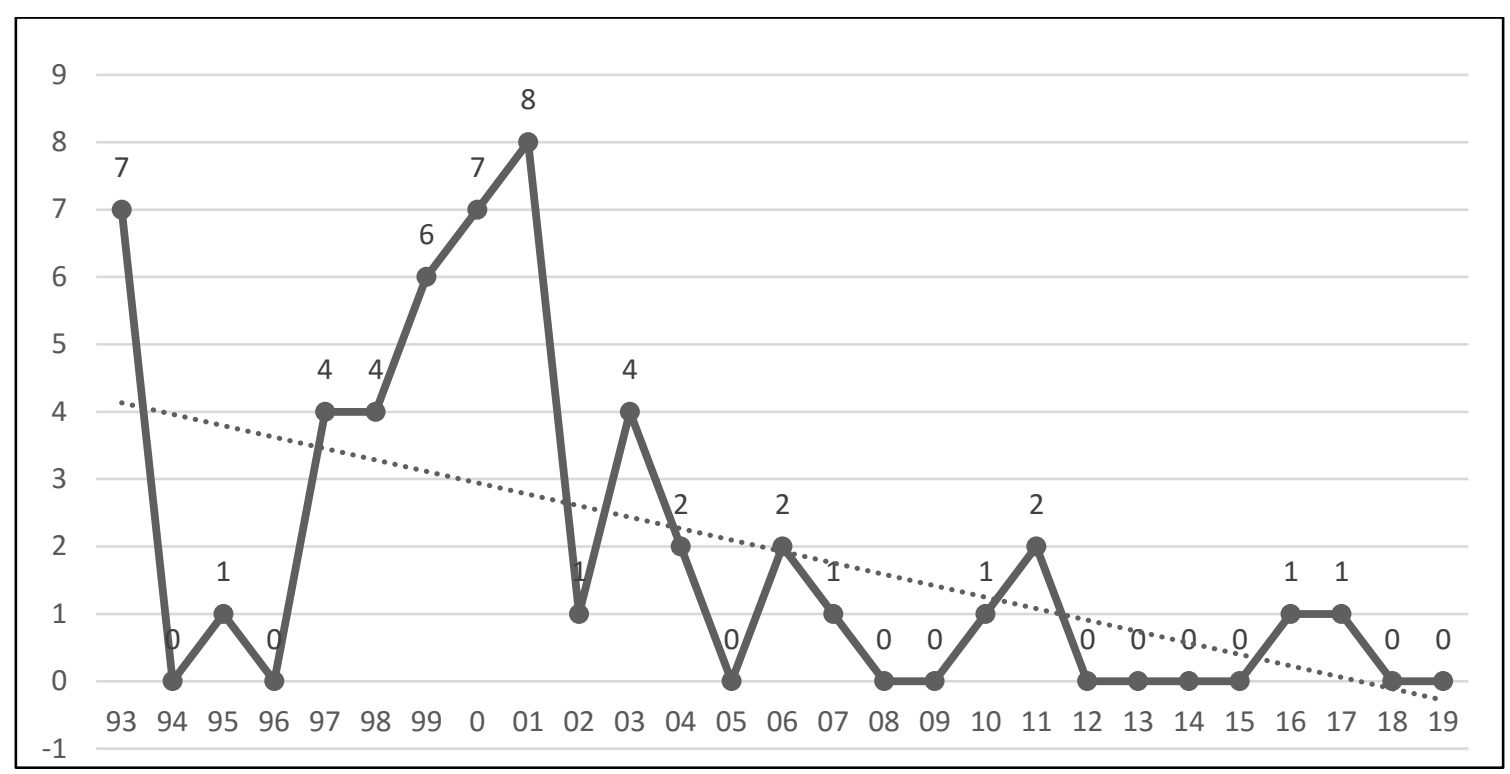

Şekil 2. Zombi İşletme Sayısının Yıllar İçinde Değişimi

Kaynak: ISO 1000 (ISO ilk 500+ISO ikinci 500, www.iso500.org.tr) verileri ile yazar tarafindan hazırlanmıştır.

Not: Yatay (x) eksen, 1993-2019 yıllarını göstermekte ve sürekli negatif öz kaynak kaydının bulunduğu dönemin başlangıcını ifade etmektedir. 1993-1996 yıllarında ve 2019 yılında İSO ilk 500 verileri dikkate alınabilmiştir.

Tablo 2. 52 Zombi İşletmenin Sektörel Dağılımı

\begin{tabular}{|c|c|c|c|c|c|}
\hline No & $\begin{array}{c}\text { ISI C } \\
\text { Rev.2 } \\
\text { Sektör } \\
\text { Kodu }\end{array}$ & $\begin{array}{l}\text { ISIC Rev. } 2 \\
\text { Sektör Sinıfi }\end{array}$ & $\begin{array}{l}\text { Zombi } \\
\text { Saylsl }\end{array}$ & $\begin{array}{l}\text { Zombi } \\
\text { Yüzdesi }\end{array}$ & $\begin{array}{l}\text { ISO } \\
1000 \\
\text { Payl }\end{array}$ \\
\hline 1 & 321 & Dokuma Sanayi & 14 & 26.9 & 15.0 \\
\hline 2 & 311 & G1da Maddeleri Sanayi & 12 & 23.1 & 15.0 \\
\hline 3 & 210 & Madencilik ve Taş ocakçılığ & 6 & 11.5 & 2.2 \\
\hline 4 & 369 & Taş ve Toprağa Dayalı Diğer Sanayi & 3 & 5.8 & 5.2 \\
\hline 5 & 384 & Taşıt Araçları Sanayi & 3 & 5.8 & 7.2 \\
\hline 6 & 312 & Başka Yerde Sınıflandırılmamış Gıda Maddeleri Sanayi & 2 & 3.8 & 1.9 \\
\hline 7 & 352 & Diğer Kimyasal Ürünler Sanayi & 2 & 3.8 & 5.4 \\
\hline 8 & 371 & Demir-Çelik Ana Metal Sanayi & 2 & 3.8 & 6.8 \\
\hline 9 & 372 & Demir-Çelik Dışında Ana Metal Sanayi & 2 & 3.8 & 2.9 \\
\hline 10 & 332 & Ağaç, Mobilya ve Mefruşat Sanayi & 1 & 1.9 & 1.1 \\
\hline 11 & 341 & Kağıt ve Kağıt Ürünleri Sanayi & 1 & 1.9 & 2.9 \\
\hline 12 & 351 & Ana Kimya Sanayi & 1 & 1.9 & 2.5 \\
\hline 13 & 382 & Makine Sanayi (Elektrikli Olanlar Hariç) & 1 & 1.9 & 3.1 \\
\hline 14 & 383 & Elektrik Makineleri, Aletleri ve Cihazları Sanayi & 1 & 1.9 & 5.4 \\
\hline 15 & 400 & Elektrik Sektörü & 1 & 1.9 & 1.6 \\
\hline
\end{tabular}

Kaynak: ISO 1000 (ISO ilk 500+ISO ikinci 500, www.iso500.org.tr) verileri ile yazar tarafindan hazırlanmıştır.

Not. 1993-1996 y1llarında ve 2019 yllında sadece İSO ilk 500 firma verileri dikkate alınabilmiştir. Sürekli negatif öz kaynak kaydının bulunduğu dönemin başlangıç yılına göre sektör dağııımı belirlenmiştir. Zombi Sayısı: İlgili sektörde analiz süresince tespit edilen zombi işletme sayısıdır. Zombi Yüzdesi: Sektörün zombi firma sayısının 52 adet zombi firma sayısına oranıdır. ISO 1000 Payı: Her yıl her bir sektörün firma sayısının 1000 firmaya oranının analiz dönemi ortalamasıdır.

Zombilik başlangıç yılının (ZBY) durumuna göre, 52 zombi işletmenin 30'u İSO ilk 500 firması, 22'si İSO ikinci 500 firması arasındadır. 13’ü (\%25'i) sermayesi ağırlıklı kamuya ait 
olan işletmelerdir ve yabancı sermaye payı ortalaması \%3,5'tur. 52 zombi işletmenin finansal özelliklerinin ortalaması konu işletmelerin 4,7 yıl (3 ila 13 yıl arasında) boyunca negatif öz kaynak ile faaliyet gösterdiğini, negatif öz kaynak tutarının aktifin \%44'ünü oluşturduğu bir başka ifade ile borçlanma oranının \%144 olduğunu göstermektedir. Zombi işletmelerde kar marjları ortalaması \%6,3 brüt kar, -\%55 dönem zararı, - \%49 aktif zararı şeklindedir. 15 sektörde yer alan zombi işletmelerin sektör dağılımında ilk üç sırayı alan sektör (Tablo 2'de verilen) negatif öz kaynak kayıtları ile (Tablo 1'de verilen) aynı olup; 1) dokuma sanayi, 2) gıda maddeleri sanayi, 3) madencilik ve taş ocakçılığ sektörü şeklindedir. En fazla zombi işletme kaydının yer aldığı ilk üç sektörün toplam zombi işletmelerden aldığı pay \%62'dir. Ayrıca bu üç sektörün zombi yoğunluğu, Tablo 2'nin son sütununda raporlanan sektörlerin ISO 1000 içindeki yoğunluğunun üzerindedir.

\subsubsection{Analiz Veri Seti}

Önceki iki alt başlık (bkz. bölüm 3.1.1 ve bölüm 3.1.2) ile seçim süreci anlatılan 52 zombi işletmesi arasından zombi başlangıç yılından $(\mathrm{ZBY}=\mathrm{t})$ bir önceki yıl $(\mathrm{ZBY}=\mathrm{t}-1)$ İSO 1000 sıralamasında yer alan ve böylece verilerine ulaşılabilen 32 işletme tespit edilmiştir. Analiz örneklemini oluşturan 32 zombi imalat işletmesinin zombi risk düzeyi iki gösterge ile belirlenmiştir. Birincisi öz kaynağının sürekli olarak (aralıksız) negatif olduğu yılların sayısı olup “zombi süresi (ZSRS)” olarak ifade edilmiştir. Zombi risk düzeyinin ikinci göstergesi, zombi olunan dönemin başlangıcında $(Z B Y=t)$ işletmenin hangi seviyede negatif öz kaynak ile faaliyet gösterdiğini ifade eden, negatif öz kaynağın aktife oranı olan "zombi derinliği $\left(\mathrm{ZDRN}_{\mathrm{t}}\right)$ " değişkenidir.

Tablo 3'te zombi süresi ve zombi derinliği değişkenleri ve bu iki zombi risk düzeyi göstergesi ile ilişkisi incelenen sekiz büyüklük (ölçek) değişkeni, iki sermaye türü değişkeni ve üç sektör değişkeninin açıklamaları ve tanımlayıcı istatistikleri yer almaktadır. Zombi risk seviyesi ile ilişkisine bakılan nispi büyüklük değerleri, işletmenin ilgili değere göre İSO 1000 sıralamasında aldığı sırayı ifade etmektedir. Bu değerler; net satış tutarı $\left(\mathrm{NS}_{\mathrm{t}-1}\right)$, üretimden elde edilen satış tutarı $\left(\mathrm{US}_{\mathrm{t}-1}\right)$, toplam aktif tutarı $\left(\mathrm{AK}_{\mathrm{t}-1}\right)$, öz kaynak tutarı $\left(\mathrm{ÖZK} \mathrm{K}_{\mathrm{t}-1}\right)$, brüt kar tutarı $\left(\mathrm{BK}_{\mathrm{t}-1}\right)$, vergi öncesi dönem karı miktarı $\left(\mathrm{DK}_{\mathrm{t}-1}\right)$, ücretli çalışan adedi (ÜÇS $\left.\mathrm{S}_{\mathrm{t}-1}\right)$ ve ihracat miktarıdır ( $\left.\mathrm{IHR}_{\mathrm{t}-1}\right)$. İkinci bağımsız değişken grubunu; işletmenin sermayesinde kamu payını $\left(\mathrm{KAMU}_{\mathrm{t}-1}\right)$ ve yabanc1 sermaye payını $\left(\mathrm{YAB}_{\mathrm{t}-1}\right)$ yüzde olarak gösteren iki sermaye türü verisi oluşturmaktadır. İşlemenin zombi risk seviyesiyle ilişkisi incelenen üçüncü değişken grubu sektör olup en fazla negatif öz kaynak ve zombi kaydının yer aldığı dokuma sanayi $\left(\mathrm{DKM}_{\mathrm{t}-1}\right)$ ve 
g1da maddeleri sanayi $\left(\mathrm{GIDA}_{\mathrm{t}-1}\right)$ sektörlerinin ayrı ayrı ve birlikte $\left(\mathrm{GDDK}_{\mathrm{t}-1}\right)$ değerlendirildiği yapay değişkenler bu grubun göstergeleridir.

Tablo 3. Örneklemin Tanımlayıcı İstatistikleri

\begin{tabular}{|c|c|c|c|c|c|c|c|}
\hline \multicolumn{3}{|c|}{ Değişkenler } & \multicolumn{5}{|c|}{ Tanımlayıcı Ístatistikler } \\
\hline Grup & Gösterge & Sembol & $\begin{array}{c}\text { Göz. } \\
\text { No }\end{array}$ & Ort. & $\begin{array}{c}\text { St. } \\
\text { Sap. }\end{array}$ & Min. & Maks. \\
\hline Zombi Risk & Zombi Süresi & ZSRS & 32 & 4,7 & 2 & 3 & 10 \\
\hline Düzеyi & Zombi Derinliği, \% & $Z_{\mathrm{ZRN}}$ & 32 & 35,1 & 78 & 1 & 449 \\
\hline & Net Satış & $\mathrm{NS}_{\mathrm{t}-1}$ & 32 & 396 & 240 & 48 & 917 \\
\hline & Üretimden Satış & $\mathrm{US}_{\mathrm{t}-1}$ & 32 & 388 & 233 & 36 & 870 \\
\hline Nispi & Aktif & $\mathrm{AK}_{\mathrm{t}-1}$ & 30 & 322 & 219 & 16 & 867 \\
\hline Büyüklük & $\ddot{O}_{z}$ kaynak & ÖZK $_{t-1}$ & 30 & 483 & 229 & 27 & 955 \\
\hline (siralama & Brüt Kar & $\mathrm{BK}_{\mathrm{t}-1}$ & 28 & 395 & 180 & 129 & 928 \\
\hline değeri) & Dönem Karl & $\mathrm{DK}_{\mathrm{t}-1}$ & 29 & 527 & 212 & 138 & 987 \\
\hline & Ücretli Çalışan & $\ddot{U} C ̧ S_{t-1}$ & 30 & 305 & 252 & 12 & 845 \\
\hline & Ihracat & $\mathrm{IHR}_{\mathrm{t}-1}$ & 22 & 376 & 193 & 65 & 767 \\
\hline Sermaye & Кати, \% & $\mathrm{KAMU}_{\mathrm{t}-1}$ & 32 & 13 & 34 & 0 & 100 \\
\hline Türü (\%) & Yabancı Ortak, \% & $\mathrm{YAB}_{\mathrm{t}-1}$ & 32 & 4,5 & 15 & 0 & 75 \\
\hline Sektör & Gida ve Dokuma & $\mathrm{GDDK}_{\mathrm{t}-1}$ & 32 & 0,5 & 0,5 & 0 & 1 \\
\hline (kukla & Gida & $\mathrm{GIDA}_{\mathrm{t}-1}$ & 32 & 0,2 & 0,4 & 0 & 1 \\
\hline değişken) & Dokuma & $\mathrm{DKM}_{\mathrm{t}-1}$ & 32 & 0,3 & 0,5 & 0 & 1 \\
\hline
\end{tabular}

Kaynak: ISO 1000 (ISO ilk 500+ ISO ikinci 500, www.iso500.org.tr) verileri ile yazar tarafindan hazırlanmıştır.

Not. 1993-1996 yıllarında ve 2019 yılında sadece İSO ilk 500 firma verileri dikkate alınabilmiştir. t: sürekli negatif öz kaynak kaydının ilk yılı veya zombi başlangıç yılı (ZBY). t-1: sürekli negatif öz kaynak kaydından bir önceki yıl veya zombi olmadan önceki yıl. ZSRS: zombi olarak geçirilen yıl sayısı. ZDRN $\mathrm{t}$ : ZBY'nda öz kaynak tutarının aktife oranının yüzdesel karşılığının mutlak değeri. $\mathrm{NS}_{\mathrm{t}-1}$ : İşletmenin ZBY'ndan bir yıl önce net satış sıralamasına göre ilk 1000 firma arasındaki sırası. $\mathrm{US}_{\mathrm{t}-1}$ : üretimden net satış tutarına göre sıralama. $\mathrm{AK}_{\mathrm{t}-1}$ : toplam aktif tutarı sıralaması. ÖZK $\mathrm{t}_{\mathrm{t}-1}$ : öz kaynak tutarı sıralaması. $\mathrm{BK}_{\mathrm{t}-1}$ : brüt kar sırası. DK $\mathrm{DK}_{\mathrm{t}-1}$ : vergi öncesi dönem kar1 sırası. ÜÇS ${ }_{1}$ : ücretli çalışan sayısına göre sıralama değeri. $\mathrm{IHR}_{\mathrm{t}-1}$ : ihracat büyüklüğüne göre sırası. $\mathrm{KAMU}_{\mathrm{t}-1}$ : işletmenin sermayesinde kamu sermaye payının yüzdesel karşılı̆̆ı. YAB $\mathrm{H}_{\mathrm{t}-1}$ : işletmenin sermayesinde yabancı sermaye payının yüzdesel değeri. GDDK $_{\mathrm{t}-1}$ : İşletmenin dokuma sanayinde veya gıda maddeleri sanayinde olması halinde bir değerini alan yapay değişken. GIDA $\mathrm{t}_{-1}$ : İşletmenin gida maddeleri sanayinde olması halinde bir değerini alan kukla değişken. $\mathrm{DKM}_{\mathrm{t}-1}$ : İşletmenin dokuma sanayinde olması halinde bir değerini alan yapay değişken.

Tablo 3'ün tanımlayıcı istatistiklerinde gözlem sayılarının 22 ila 32 arasında değişmesinde ilgili dönemde konu veriye ilişkin bilgi raporlayan firma sayısı belirleyici olmuştur. Tanımlayıcı istatistiklere göre 32 zombi işletmenin öz kaynağı ilk kez negatife döndükten sonra bu işletmeler ortalama olarak beş yıl negatif öz kaynak ile faaliyetine devam etmiş ve üretimden satış sıralamasına göre Türkiye'nin en büyük 1000 imalat şirketi arasında yer almaya devam etmiştir. 10 yıl ile en uzun negatif öz kaynak kaydı (en uzun zombilik süresi) Dardanel Önentaş Gıda San. A.Ş.'ne aittir. 32 firmanın öz kaynağının negatif olduğu ilk yıl ortalama olarak negatif öz kaynakları aktifinin \%35'i kadardır. Zombi olunan ilk yıl negatif öz kaynak yoğunluğu (zombi derinliği) değişkeninin ortalamadan sapması 78 standart sapma ile yüksek olup maksimum değer olan \%449 (borçlanma oranı \%549) Et ve Balık Ürünleri A.Ş.'nin 1995 yılına aittir. 
1000 firma arasında sıralamayı gösteren nispi büyüklük ölçütleri ortalamasına göre 32 zombi işletme, nispeten büyük (ortalama 400. sırada) işletmelerden oluşmuştur. Ölçek değişkenleri, ücretli çalışan sayısı sıralama ortalaması (305) ila dönem karı sıralama ortalaması (527) arasındadır. Ücretli çalışan sayısında en yüksek sıralama (12. sıra) Türkiye Taşkömürü Kurumu Kozlu Taşkömürü İşletme Müessesesinin 1997 yılı 5,417 adet ücretle çalışan sıralamasını göstermektedir. Aktif (16. sıra), net satış (48. sıra), üretimden satış (36. sıra) ve öz kaynak büyüklügü (27. sıra) açısından en yüksek (sıralamada en önce) değerleri alan işletme Et ve Balık Ürünleri A.Ş'dir ve bu sıralama değerleri firmanın zombi olmadan önceki yılı olan 1994 yılına aittir. Brüt karlılık açısından en yüksek sıralama değeri (129. sıra) Yeşim Tekstil Sanayi ve Ticaret A.Ş.'nin 2000 yılına aittir. 1997 yılında Fiskobirlik Fındık Tarım Satış Kooperatifleri Birliği’nin dönem karı, en önde gelen dönem karıdır. En yüksek ihracat sıralaması İstanbul Çorap San. A.Ş.'nin 1996 yılında aldığg 65 . sıradır.

32 işletmenin sermayesinin kamuya ait olma oranı ortalama \%13'tür ve yabancı sermayenin toplam sermaye içinde payı \%4,5'tir. Dolayısı ile 32 zombi imalat firmasının ağırlıklı olarak yerel ve özel sermaye sahipli olduğu söylenebilir. 32 imalat işletmesinin \%50'sini dokuma sanayi (10 adet) ve gıda maddeleri sanayi (6 adet) sektörlerinde faaliyet gösteren işletmeler oluşturmaktadır.

\section{2. Analiz Yöntemi ve Bulguları}

Çalışma analizinin amacı, zombi işletmelerin zombi olmadan önceki finansal özelliklerinin zombi risk seviyesi ile olan ilişkisinin araştırılmasıdır. Bu amaçla 1993-2019 yılları arasında İSO 1000 arasından seçilen 32 zombi imalat işletmesinin zombi olarak geçirdiği süre ve zombi olduğu ilk yılda öz kaynağının aktife göre oranı göstergeleri ile ifade edilen zombi risk düzeyinin $^{3}$, zombi olmadan önceki yıla ait üç değişken grubunun 13 göstergesi ile ilişkisi tek değişkenli yatay kesit regresyon analizi, korelasyon analizi ve bir bağımlı değişken (ZSRS) için tek değişkenli sıralı logit modeli ile incelenmiştir.

Zombi risk seviyesi değişkenlerinin bağımlı değişken olduğu tek değişkenli yatay kesit regresyon analizi tahminlerine ait istatistikler ve bağımlı değişkenler ile bağımsız değişkenler arasındaki korelasyon katsayıları Tablo 4 (ZSRS) ve Tablo $7\left(Z^{2} N_{t}\right)$ ile sunulmuştur. Zombi süresi (ZSRS) zombi risk düzeyini 3 ila 10 arasında hiyerarşik olarak sıralayan (sıralama değeri yükseldikçe risk artışını ifade eden) bir değişkendir. Bu sebeple ZSRS sıralı bağımlı değişkeni ile açıklayıcı değişkenler arasında tek değişkenli sıralı tercih modelleri olan sıralı logit ve sıralı

\footnotetext{
${ }^{3}$ Bir firmanın zombi durumunun yoğunluğunu değerlendirmek için borçların aktif payı yanında bu durumun ne kadar sürdüğü de incelenmesi gereken unsurlardandır (Urionabarrenetxea vd. 2017: 408)
} 
probit model tahminleri yapılmış ve tahmin istatistikleri Tablo 5 (ZSRS, logit) ve Tablo 6 (ZSRS, probit) ile verilmiştir.

Tablo 4. ZSRS için Yatay Kesit Regresyon Analizi ve Korelasyon Analizi Bulguları

\begin{tabular}{|c|c|c|c|c|c|c|c|c|c|}
\hline \multirow{2}{*}{\multicolumn{3}{|c|}{\begin{tabular}{|l|} 
Bağımlı Değissken: \\
Zombi Süresi (ZSRS) \\
\end{tabular}}} & \multicolumn{7}{|c|}{ Yatay Kesit Regresyon Analizi Istatistikleri } \\
\hline & & & \multicolumn{2}{|c|}{ Tahmin ist. } & \multicolumn{3}{|c|}{ Tahminci ist. } & \multicolumn{2}{|c|}{ Dĕg. Var. Test ist. } \\
\hline & $\begin{array}{l}\text { Bă̆ımsız } \\
\text { Değissken }\end{array}$ & $\begin{array}{l}\text { Korelasyon } \\
\text { Katsaylst }\end{array}$ & $\begin{array}{l}\text { Değişken } \\
\text { Katsayısı }\end{array}$ & tist. & $N$ & F ist. & $R 2$ & $B P / C W$ & White \\
\hline \multirow{8}{*}{$\begin{array}{c}\text { Nispi } \\
\text { Büyüklük } \\
\text { (stralama } \\
\text { değeri) }\end{array}$} & $N S_{t-1}$ & -0.28 & $-0,002 *$ & $-1,87$ & 32 & $3,48^{*}$ & 0,080 & 0,76 & 0,99 \\
\hline & $U S_{t-1}$ & -0.28 & $-0,002^{*}$ & $-1,90$ & 32 & 3,6 & 0 & 0,59 & 1,05 \\
\hline & $A K_{t-1}$ & $-0,48 * * *$ & $-0,004 * *$ & $-2,70$ & 30 & $7,28 * *$ & 0,227 & $6,64 * *$ & $9,12 * *$ \\
\hline & $\ddot{O} Z K_{t-1}$ & $\leqslant *$ & $-0,005 * * *$ & $-4,46$ & 30 & $19,92 * * *$ & 0,283 & $4,76^{* *}$ & 4,25 \\
\hline & $B K_{t-1}$ & -0 & $-0,005^{* * *}$ & $-2,82$ & 28 & $7,95^{* *}$ & 0,194 & $4,24 * *$ & 4,24 \\
\hline & $D K_{t-1}$ & $-0,40 * *$ & $-0,004 * * *$ & $-3,97$ & 29 & $15,72 * * *$ & 0,161 & 2,45 & 2,69 \\
\hline & $\ddot{U} C S_{t-1}$ & $-0,55 * * *$ & $-0,003 * * *$ & $-3,24$ & 30 & $12,27 * * *$ & 0,301 & $5.51 * *$ & $6,11 *$ \\
\hline & $I H R_{t-1}$ & $-0,39 *$ & $-0,004 * *$ & $-2,50$ & 22 & $6,24 * *$ & 0,155 & 1,47 & 3,15 \\
\hline \multirow{2}{*}{$\begin{array}{l}\text { Sermaye } \\
\text { Payl (\%) }\end{array}$} & $K A M U_{t-1}$ & -0.03 & $-0,002$ & $-0,22$ & 32 & 0,05 & 0,001 & 0,28 & 0,76 \\
\hline & $Y A B_{t-1}$ & 0.22 & 0,030 & 1,54 & 32 & 2,37 & 0,046 & 0,16 & 0,14 \\
\hline \multirow{3}{*}{$\begin{array}{c}\text { Sektör } \\
\text { (kukla } \\
\text { değişken) }\end{array}$} & $G D D K_{t-1}$ & 0.11 & 0,438 & 0,60 & 32 & 0,36 & 0,012 & 0,14 & 0,15 \\
\hline & $G I D A_{t-1}$ & 0.12 & 0,628 & 0,55 & 32 & 0,31 & 0,015 & 1,45 & 1,87 \\
\hline & $D K M_{t-1}$ & 0.01 & 0,064 & 0,09 & 32 & 0,01 & 0,000 & 0,47 & 0,50 \\
\hline
\end{tabular}

Kaynak: ISO 1000 (ISO ilk 500+ ISO ikinci 500, www.iso500.org.tr) verileri ile yazar tarafindan hazırlanmıştır.

Not. Tablo 4, ZSRS ile 13 değişken arasındaki korelasyon katsayılarını ve her bir bağımsız değişken ile kurulan tek değişkenli yatay kesit regresyon tahminlerinin parametrelerini içermektedir. Temel hipotezleri değişen varyans (değ.var.) yoktur olan BP/CW ve White testleri bazı eşitliklerde ret edildiği için dirençli (robust) standart hatalar (t-istatistikleri) kullanılmıştır. ***: istatistiki olarak \%1 önem seviyesini, **:\%5 anlamlılık düzeyini, *: \%10 önem düzeyini ifade etmektedir.

Tablo 5. ZSRS Bağımlı Değişkeni için Sıralı Logit Tahmin İstatistikleri

\begin{tabular}{|c|c|c|c|c|c|c|c|}
\hline Stralı Logit Tahr & in Istatistikler & Bağımlı L & sken: 2 & Sü̈ & ZSRS) & & \\
\hline & Değişkenler & Katsayl & zist. & $N$ & LR chi2 & $P>$ chi2 & PseudoR2 \\
\hline & $N S_{t-1}$ & $-0,003^{*}$ & $-1,88$ & 32 & $3,83^{*}$ & 0,050 & 0,037 \\
\hline & $U S_{t-1}$ & $-0,003^{*}$ & $-1,92$ & 32 & $4,01 *$ & 0,045 & 0,045 \\
\hline & $A K_{t-1}$ & $-0,005 * *$ & $-2,37$ & 30 & $6,80 * * *$ & 0,009 & 0,070 \\
\hline Nispi Виуикlик & $\ddot{O} Z K_{t-1}$ & $-0,007 * * *$ & $-3,01$ & 30 & $12,57 * * *$ & 0,000 & 0,129 \\
\hline (J) & $B K_{t-1}$ & $-0,007 * *$ & $-2,56$ & 28 & $8,90 * * *$ & 0,003 & 0,100 \\
\hline & $D K_{t-1}$ & $-0,006 * *$ & $-2,49$ & 29 & $8,27 * * *$ & 0,004 & 0,087 \\
\hline & $\ddot{U} C ̧ S_{t-1}$ & $-0,006 * * *$ & $-2,93$ & 30 & $11,67 * * *$ & 0,001 & 0,120 \\
\hline & $I H R_{t-1}$ & $-0,004 *$ & $-1,88$ & 22 & $3,88^{*}$ & 0,049 & 0,051 \\
\hline Sermaye Payı & $K A M U_{t-1}$ & $-0,002$ & $-0,14$ & 32 & 0,02 & 0,886 & 0,000 \\
\hline$(\%)$ & $Y A B_{t-1}$ & 0,027 & 1,29 & 32 & 1,50 & 0,221 & 0,015 \\
\hline & $G D D K_{t-1}$ & 0,430 & 0,66 & 32 & 0,44 & 0,506 & 0,004 \\
\hline değisken) & $G I D A_{t-1}$ & 0,404 & 0,49 & 32 & 0,24 & 0,624 & 0,002 \\
\hline & $D K M_{t-1}$ & 0,206 & 0,30 & 32 & 0,09 & 0,764 & 0,001 \\
\hline
\end{tabular}

Kaynak: ISO 1000 (ISO ilk 500+ ISO ikinci 500, www.iso500.org.tr) verileri ile yazar tarafindan hazırlanmıştır.

Not. Tablo 5, ZSRS ve her bir bağımsız değişken ile kurulan tek değişkenli sıralı logit modeli parametre tahminlerine ait istatistikleri içermektedir. ***: istatistiki olarak \%1 önem seviyesini, **:\%5 anlamlılık düzeyini, *: \%10 önem düzeyini ifade etmektedir. 
Tablo 6. ZSRS Bağımlı değişkeni için Sıralı Probit Tahmin İstatistikleri

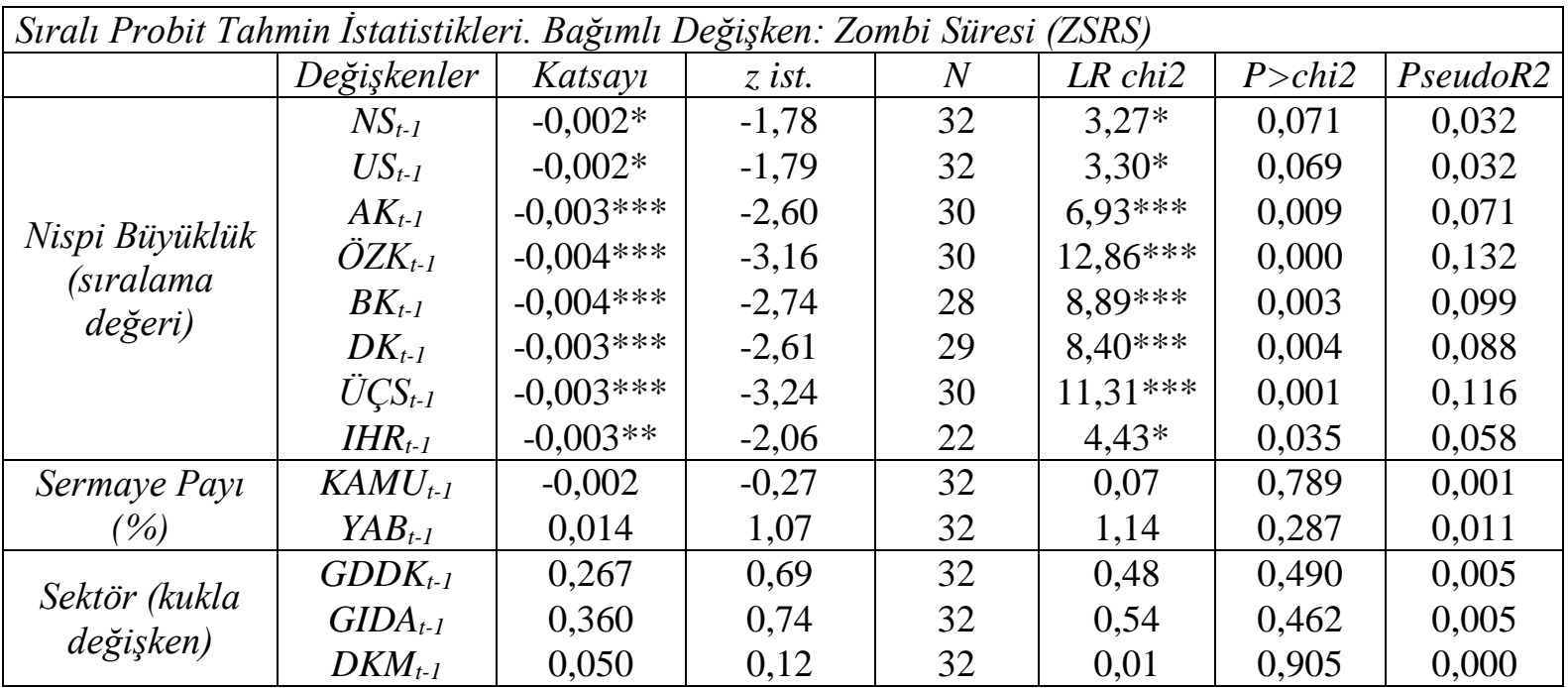

Kaynak: ISO 1000 (ISO ilk 500+ISSO ikinci 500, www.iso500.org.tr) verileri ile yazar tarafindan hazırlanmıștır.

Not. Tablo 6, ZSRS ve her bir bağımsız değişken ile kurulan tek değişkenli sıralı probit modeli parametre tahminlerine ait istatistikleri içermektedir. ***: istatistiki olarak \%1 önem seviyesini, **:\%5 anlamlılık düzeyini, *: \%10 önem düzeyini ifade etmektedir.

Nispi büyüklük göstergeleri, işletmelerin ilgili değer açısından İSO 1000 içinde hangi sırada yer aldığını ifade etmekte olduğundan zombi seviyesi ile olan negatif ilişkiler, firmanın sıralaması yüksek (sıralamada daha geride ise veya firma ilgili değer açısından daha küçükse) ise zombi risk düzeyinin daha düşük olduğunu ifade etmektedir. Bir başka ifade ile nispi büyüklük değişkenlerinin zombi düzeyi ile olan negatif ilişkileri, ilgili ölçek değişkenine göre nispeten daha büyük olan firmaların, daha uzun süre zombi olarak faaliyet gösterdiğine veya zombi sürecine daha derin başladığına (zombi döneminin başlangıcında daha yüksek negatif öz kaynak/aktif oranına sahip olduğuna) işaret etmektedir

Tablo 4'ün üçüncü sütununda bulunan değerlere göre ZSRS ile nispi büyüklük değişkenlerinin tamamı negatif korelasyon ilişkisi içindedir ancak toplam aktif, öz kaynak, brüt kar, dönem karı, ihracat tutarı ve çalışan sayısı ile olan korelasyon katsayıları istatistiki açıdan anlamlıdır. Tablo 4'te yer alan yatay kesit regresyon tahminleri ile Tablo 5 ve Tablo 6'da sunulan lojistik regresyon tahminleri ise net satış ve üretimden satış büyüklükleri de dahil bütün büyüklük değişkenlerinin ZSRS üzerinde istatistiki açıdan anlamlı negatif etkiye sahip olduğunu teyit etmektedir. Zombi olmadan önceki yıl satış, aktif, öz kaynak, brüt kar, dönem karı, çalışan sayısı ve ihracat tutarı açısından daha büyük ölçekli olan işletmelerin daha uzun süre negatif öz kaynak ile faaliyet gösterdiği veya daha uzun süre zombilik durumunda bulunduğu söylenebilir. Bu işletmeler zombi süresi bakımından zombi risk düzeyi daha yüksek olma eğilimindedir. Ölçeğe ilişkin bu sonuç, İspanya' da en riskli zombilerin daha büyük ölçekli firmalar olduğunu ortaya koyan Urionabarrenetxea vd. (2017)'nin bulgulariyla ve Avrupa 
Birliği ülkelerinde negatif öz kaynağın büyük oranda büyük ölçekli firmalara ait olduğunu gösteren Urionabarrenetxea vd. (2016)'nin tespitleriyle örtüşmektedir.

Zombi olarak geçirilen süre ile sermayenin kamu veya yabancı ağırlıklı olması ve işletmenin gıda ve/veya dokuma sektörlerinde yer alması durumu arasındaki ilişkiler istatistiki açıdan önemli değildir. Zombi işletmelerin kamu-özel sermayeli, yerel-yabancı sermayeli olmasının ve gıda-dokuma sanayi sektörlerinde yer almasının zombi olarak geçirilen süre bakımından risk seviyesi ile bir ilişkisinin bulunmadığı söylenebilir.

Tablo 7. ZDRN ${ }_{\mathrm{t}}$ için Yatay Kesit Regresyon Analizi ve Korelasyon Analizi Bulguları

\begin{tabular}{|c|c|c|c|c|c|c|c|c|c|}
\hline \multirow{2}{*}{\multicolumn{3}{|c|}{$\begin{array}{l}\text { Bağımlı Değişken: } \\
\text { Zombi Derinliği }\left(Z D R N_{t}\right)\end{array}$}} & \multicolumn{7}{|c|}{ Yatay Kesit Regresyon Analizi İstatistikleri } \\
\hline & & & \multicolumn{2}{|c|}{ Tahmin ist. } & \multicolumn{3}{|c|}{ Tahminci ist. } & \multicolumn{2}{|c|}{ Dĕ. Var. Test ist. } \\
\hline & $\begin{array}{l}\text { Bă̆ımsız } \\
\text { Değişken }\end{array}$ & $\begin{array}{c}\text { Korelasyon } \\
\text { Katsayis1 }\end{array}$ & $\begin{array}{l}\text { Değişken } \\
\text { Katsayıs1 }\end{array}$ & t ist. & $\mathrm{N}$ & $\mathrm{F}$ ist. & R2 & $\mathrm{BP} / \mathrm{CW}$ & White \\
\hline \multirow{8}{*}{$\begin{array}{c}\text { Nispi } \\
\text { Büyüklük } \\
\text { (siralama } \\
\text { değeri) }\end{array}$} & $N S_{t-1}$ & -0.21 & $-0,070$ & $-0,85$ & 32 & 0,72 & 0,046 & $28,42 * * *$ & $6,78 * *$ \\
\hline & $U S_{t-1}$ & -0.22 & $-0,073$ & $-0,84$ & 32 & 0,70 & 0,048 & $30,51 * * *$ & $7,08 * *$ \\
\hline & $A K_{t-1}$ & -0.26 & $-0,097$ & $-1,05$ & 30 & 1,10 & 0,069 & $24,52 * * *$ & $5,23^{*}$ \\
\hline & $\ddot{O} Z K_{t-1}$ & $-0,37 * *$ & $-0,129$ & $-1,06$ & 30 & 1,25 & 0,135 & $36,38 * * *$ & $17,20 * * *$ \\
\hline & $B K_{t-1}$ & 0.02 & 0,011 & 0,43 & 28 & 0,18 & 0,001 & 0,04 & 0,57 \\
\hline & $D K_{t-1}$ & -0.04 & $-0,014$ & $-0,61$ & 29 & 0,37 & 0,001 & 0,70 & 0,50 \\
\hline & $\ddot{U} C ̧ S_{t-1}$ & -0.22 & $-0,070$ & $-1,04$ & 30 & 1,09 & 0,048 & $17,19 * * *$ & 2,76 \\
\hline & $I H R_{t-1}$ & 0.02 & 0,010 & 0,22 & 22 & 0,05 & 0,000 & 0,50 & 0,95 \\
\hline Sermaye & $K A M U_{t-1}$ & $0,48^{* * *}$ & 1,120 & 1,19 & 32 & 1,41 & 0,233 & $93,96 * * *$ & $12,47 * * *$ \\
\hline Payı (\%) & $Y A B_{t-1}$ & -0.05 & $-0,249$ & $-0,79$ & 32 & 0,62 & 0,002 & 1,48 & 0,17 \\
\hline Sektör & $G D D K_{t-1}$ & 0.18 & 28,13 & 1,02 & 32 & 1,05 & 0,034 & $14,76 * * *$ & 1,24 \\
\hline (kukla & $G I D A_{t-1}$ & $0,42 * *$ & 83,30 & 1,25 & 32 & 1,57 & 0,180 & $63,08 * * *$ & $6,74 * * *$ \\
\hline değişken) & $D K M_{t-1}$ & -0.16 & $-26,33$ & $-1,28$ & 32 & 1,64 & 0,025 & $6,75^{* * *} *$ & 0,54 \\
\hline
\end{tabular}

Kaynak: ISO 1000 (ISO ilk 500+ ISO ikinci 500,www.iso500.org.tr) verileri ile yazar tarafindan hazırlanmiştır.

Not. Tablo 7, $\mathrm{t}$ döneminde zombi derinliği $\left(Z_{D R N}\right)$ ile 13 bağımsız değişkenin $\mathrm{t}-1$ dönemi değeri arasındaki korelasyon katsayılarını ve her bir bağımsız değişken ile kurulan tek değişkenli yatay kesit regresyon tahminlerinin parametrelerini içermektedir. Temel hipotezleri değişen varyans (değ.var.) yoktur olan BP/CW ve White testleri çoğu eşitlikte ret edildiği için dirençli (robust) standart hatalar (t-istatistikleri) kullanılmıştır. ***: istatistiki olarak $\% 1$ önem seviyesini, **:\%5 anlamlılık düzeyini, *: \%10 önem düzeyini ifade etmektedir.

Tablo 7'nin ZDRN $\mathrm{t}_{\mathrm{t}}$ ile bağımsız değişkenler arasındaki korelasyon ilişkisini gösteren değerlere göre, zombi olmadan önceki yıl öz kaynağı nispeten daha yüksek olan, sermayesinde kamu payı fazla olan ve gıda maddeleri sanayinde faaliyet gösteren zombi şirketlerinin zombi olarak geçirdikleri sürenin başlangıç yılında negatif öz kaynak/aktif oranları daha yüksektir. Ancak regresyon analizi sonuçları bu sonucu teyit etmediği için büyüklük, sermaye yapısı ve sektör değişkenlerinin zombilik derinliği açısından zombilik riskine etki etmediği ifade edilebilir.

Sonuç olarak zombilik süresi başlangıcından bir yıl önce net satışları, üretimden satışları, aktifi, öz kaynağı, brüt karı, dönem karı, çalışan sayısı ve ihracatı nispeten yüksek olan firmalar daha uzun süre negatif öz kaynak ile faaliyet göstermeye (daha uzun süreli zombi olmaya) meyillidir. 


\section{Sonuç}

Zombi işletme, finansal açıdan sıkıntılı olduğu halde çeşitli kredi veya kamu kurumu destekleri ile faaliyetini sürdüren firmaları ifade etmektedir. Zombi işletmelerin kendi iflaslarından çok sağlıklı firmalara aktardıkları riskler ile faaliyet gösterdikleri sektöre ve ekonomiye zarar verdiğini ortaya koyan çalışmalar yapılmıştır. Bu çalışmaların başlangıcını Japonya’nın uzun süreli ekonomik durgunluğunu 1990'lı yılların sonlarından itibaren inceleyen çalışmalar oluşturmuş ve daha sonra Avrupa Ülkelerinde araştırmalar yapılmıştır. Son yıllarda zombi işletme-ekonomik gelişme ilişkisi yanı sıra zombi firmaların finansal özelliklerini ve zombi olmayan firmalardan farklılıklarını inceleyen çalışmaların da yapıldığı görülmüştür. Ampirik çalışmalarda finansal destek aldıkları ve/veya finansal açıdan sıkıntıda oldukları çeşitli göstergelerle belirlenen işletmeler zombi olarak ifade edilmiştir. Belirli bir süre negatif öz kaynak ile ayakta kalabilen zombi işletmeler ise çalışmalarda genellikle riski en yüksek eksta zombi işletmeler olarak ifade edilmiştir.

$\mathrm{Bu}$ çalışmada, Türkiye verileri ile yeterince incelenmediği görülen zombi işletmelerin Türkiye'de varlığı, özellikleri incelenmiş, zombi işletmelerin risk düzeyi belirlenmiş ve zombi olmadan önceki yılın hangi özelliklerinin zombilik risk düzeyi ile ilişkili olduğu analiz edilmiştir. Çalışmanın veri seti, Türkiye'nin en büyük sanayi işletmelerini yıl bazında sıralayan İSO 1000 veri tabanından temin edilmiştir. Negatif öz kaynak kaydı kriterine göre işletmelerin zombi olup olmadığına karar verilmiş olup 1993-2019 yıllarını kapsayan 27 yıllık dönemde İSO 1000 firmalarında 567 adet negatif öz kaynak kaydına rastlanmıştır. En az üç yıl sürekli negatif öz kaynak kaydı olan 52 zombi işletme ve bu işletmeler arasından zombi olmadan önceki yıl verisi bulunan 32 zombi işletme belirlenmiştir. Öncelikle 567 negatif öz kaynak kaydının ve 52 zombi işletmenin yıllara, sektöre göre dağılımı ve finansal özellikleri ham veriler ile incelenmiştir. 32 zombi işletme üzerinde ise zombi olmadan önceki yılın finansal özelliklerinin zombilik risk düzeyi ile ilişkisi yatay kesit, lojistik regresyon ve korelasyon katsayıları ile araştırılmıştır. Zombi olarak geçirilen süre (zombi süresi) ve negatif öz kaynağın aktife oranı (zombi derinliği) ile temsil edilen zombi risk düzeyinin; firma büyüklüğü, sermaye türü ve sektör göstergeleri ile ilişkisi analiz edilmiştir.

Veri seti incelemesi sonuçlarına göre; İSO 1000 imalat sanayi işletmelerinde 1993-2019 yıllarında görülen negatif öz kaynaklı işletme sayısı ve üç yıldan uzun süreli negatif öz kaynaklı zombi işletme sayısı yıllar içinde azalma eğilimdedir ve 2001 ve 2009 yıllarından sonra azalma hızı daha belirgindir. 557 negatif öz kaynak ve 52 zombi işletmenin sektörel dağılımında en yoğun sektörler sırası ile 1) dokuma sanayi, 2) gıda maddeleri sanayi ve 3) madencilik ve taş ocakçılığı sektörleridir. Negatif öz kaynak ve zombi firma veri seti ortalamalarına göre; her iki 
grupta da özel sektör payı ve yerel sermaye payı yüksektir. Brüt katma değerleri düşük (\%4 ve $\% 6,3)$ ve net karlılıkları önemli düzeyde (-\%54,6 ve -\%55) negatiftir. 52 zombi işletmenin zombi kalma süresi ortalama 4,7 yıldır ve zombi derinliği \%44'tür.

32 zombi işletmenin zombi olmadan önceki yılının finansal özellikleri ile zombi risk düzeyini ilişkilendiren analiz bulguları; büyüklük göstergeleri (satış, aktif, öz kaynak, kar, ihracat ve çalışan sayısı) ile zombi süresi arasında pozitif ilişki olduğunu göstermiştir. 19932019 yılları arasında İSO 1000 imalat sanayi işletmeleri arasından zombi olmadan önceki yıl nispeten daha büyük olan işletmeler daha uzun süre negatif öz kaynak ile (daha uzun süre zombi olarak) faaliyet göstermiştir. Nispeten büyük firmaların zombi olarak geçirilen süre bakımından zombi risk düzeyi daha yüksek olma eğilimindedir. Sonuç olarak, zombi olmadan önce nispeten daha büyük olan firmaların zombi risk seviyesi daha yüksektir.

$\mathrm{Bu}$ alanda yapılacak çalışmalara farklı ölçekli firmaların, üretim sektörü dışındaki sektörlerin ve daha çok değişkenin dahil edilmesinin ayrıca zombi firmaları, finansal açıdan sağlıklı firmalardan ayıran özelliklere odaklanılmasının zombi firmaların tahmin edilmesi açısından faydalı olacağı düşünülmektedir. 


\section{KAYNAKÇA}

Ahearne, A.G., \& Shinada, N. (2005). “Zombie Firms and Economic Stagnation in Japan”. International Economics \& Economic Policy, 2(4), 363-381. https://doi.org/10.1007/s10368-005-0041-1

Banerjee, R. \& Hofmann, B. (2018). “The Rise of Zombie Firms: Causes And Consequences". BIS Quarterly Review, September 2018, 67-78. Retrieved from https://www.bis.org/publ/qtrpdf/r_qt1809g.htm

Blažková, I. , \& Dvouletý, O. (2020). “Zombies: Who Are They and How Do Firms Become Zombies?”. Journal of Small Business Management, 1-27. https://doi.org/10.1080/00472778.2019.1696100

Caballero, R.J., Hoshi, T., \& Kashyap, A. K. (2008). “Zombie Lending and Depressed Restructuring in Japan”. The American Economic Review, 98(5), 1943-1977. https://doi.org/10.1257/aer.98.5.1943

Dinçer, N.N, Pektekin, P. \& Tekin Koru, A. (2019). Zombi Firmaların İstihdam ve Verimliliğe Etkisi (Özet). TEK, 20. Ulusal İktisat Sempozyumu, 17-18 Ekim 2019, Çukurova Üniversitesi, Adana, Türkiye.

Fang, J., Gozgor, G., Lau, C.-K. M., Wu, W., \& Yan, C. (2020). "Listed Zombie Firms and Top Executive Gender: Evidence From an Emerging Market". Pacific-Basin Finance Journal, 62, 1-17. https://doi.org/10.1016/j.pacfin.2020.101357

Fukuda, S.-I., Kasuya, M., \& Nakajima, J. (2006). Deteriorating Bank Health and Lending in Japan: Evidence from Unlisted Companies under Financial Distress. Journal of the Asia Pacific Economy, 11(4), 482501. https://doi.org/10.1080/13547860600924138

Hoshi, T. (2006). "Economics of the Living Dead". The Japanese Economic Review, 57, 30-49. https://doi.org/10.1111/j.1468-5876.2006.00354.x

Imai, K. (2016). "A Panel Study of Zombie SMEs in Japan: Identification, Borrowing and Investment Behavior". Journal of The Japanese and International Economies, 39, 91-107. https://doi.org/10.1016/j.jjie.2015.12.001

Javaheriafif, S. (2017). UK Corporate Capital Structure And Zombies: An Econometric Analysis. (Unpublished $\mathrm{PhD}$ thesis). University of Nottingham, Nottingham University Business Scholl.

Kane, E. J. (1987). "Dangers of Capital Forbearance: The Case of the FSLIC and “Zombie” S\&Ls". Contemporary Economic Policy, 5(1), 77-83. doi:10.1111/j.1465-7287.1987.tb00247.x

Kaplanoğlu, E. \& Yükçü, C. (2019). Borsa İstanbul'da Zombi Firmaların Varlığının Araştırılması (Özet). III. International Applied Social Sciences Congress, 4-6 Nisan 2019, İzmir, Türkiye.

Machek, O. (2018). "Determinants of Becoming a Zombie Firm: A Pitch". Journal of Accounting and Management Information Systems, 17(4), 677-684. https://doi.org/10.24818/jamis.2018.04009

McGowan, M. A., Andrews, D. \& Millot, V. (2017). "The Walking Dead? Zombie Firms and Productivity Performance in OECD Countries". OECD Economics Department Working Papers No: 1372. ECO/WKP(2017)4, Paris: OECD Publishing

Mohrman, M. B. \& Stuerke, P.S. (2014). "Stockholders' Equity at Campbell Soup: How Can Equity Be Negative?". Accounting Education, 23(4), 386-405. https://doi.org/10.1080/09639284.2014.910814

On Birinci Kalkınma Planı (2019). Türkiye Cumhuriyeti Cumhurbaşkanlı̆̆l Strateji ve Bütçe Başkanlı̆̆l, On Birinci Kalkınma Planı (2019-2023). http://www.sbb.gov.tr/wp-content/uploads/2019/07/On-BirinciKalkinma-Plani.pdf, Erişim Tarihi: 28.08.2019

Shen, G., \& Chen, B. (2017). "Zombie Firms and Over-Capacity in Chinese Manufacturing”. China Economic Review, 44, 327-342. https://doi.org/10.1016/j.chieco.2017.05.008

Urionabarrenetxea, S., San-Jose, L., \& Retolaza, J. L. (2016). "Negative Equity Companies in Europe: Theory and Evidence”. Business: Theory and Practice, 17(4), 307-316. ?”. https://doi.org/10.3846/btp.17.11125

Urionabarrenetxea, S., Garcia-Merino, J. D., San-Jose, L., \& Retolaza, J. L. (2017). "Living with Zombie Companies: Do We Know Where the Threat Lies?”. European Management Journal, 36(3), 408-420. https://doi.org/10.1016/j.emj.2017.05.005

Wang, Y., \& Zhu, Y. (2020). "The Financing and Investment Crowding-out Effect of Zombie Firms on Nonzombie Firms: Evidence from China". Emerging Markets Finance and Trade, 1-27. https://doi.org/10.1080/1540496X.2019.1711370

Zhu, H., He, F, Wang, S., Ye, Q. \& Liang, C. (2019). "Zombie Firms and Debt Accumulation: A Theoretical Framework and Chinese Experience". China and World Economy,27(6), 104-126. https://doi.org/10.1111/cwe.12298

Web Kaynakları:

http://www.iso500.org.tr

http://www.sbb.gov.tr 